\title{
Taxonomic review of the genus Erythrocricus Schubart, 1962 (Diplopoda, Spirobolida, Rhinocricidae)
}

\author{
Patrícia Elesbão Silva RODRIGUES ${ }^{1, *}$ \& Everton Nei Lopes RODRIGUES ${ }^{2}$ \\ ${ }^{1,2}$ Laboratório de Diversidade e Sistemática de Arachnida - LaDiSA, Programa de Pós-Graduação em \\ Biologia, Universidade do Vale do Rio dos Sinos. Avenida Unisinos 950, \\ 93022-000 São Leopoldo, RS, Brazil. \\ *Corresponding author: patiesilva@yahoo.com.br \\ 2Email: enlrodrigues@unisinos.br \\ 1 ○ https://orcid.org/0000-0003-4448-3940 \\ 2 (은tps://orcid.org/0000-0002-9814-0954 \\ ${ }^{1}$ urn:1sid:zoobank.org:author:7D9151AF-4A51-4D87-9057-991DC2E966D3 \\ ${ }^{2}$ urn:1sid:zoobank.org:author:9288C215-D60B-431E-86EA-541066F82169
}

\begin{abstract}
We review the genus Erythrocricus Schubart, 1962 based on the type material of the species Erythrocricus sanguineostriatus (Schubart, 1962). We propose a new diagnosis, redescribe the type species, and propose a new synonymy and a new combination. In addition, a male-based key to both species recognized, including Erythrocricus electrofasciatus (Schubart, 1957), comb. nov. ex. Rhinocricus, is given.
\end{abstract}

Keywords. Millipedes, taxonomy, Brazil, Neotropical.

Rodrigues P.E.S.. \& Rodrigues E.N.L. 2021. Taxonomic review of the genus Erythrocricus Schubart, 1962 (Diplopoda, Spirobolida, Rhinocricidae). European Journal of Taxonomy 748: 177-187.

https://doi.org/10.5852/ejt.2021.748.1353

\section{Introduction}

The order Spirobolida Bollman, 1893 with more than 1000 described species is divided into three suborders, Spirobolidea Bollman, 1893, Trigoniulidea Attems, 1909 and Rhinocricidea Brölemann, 1913 (Enghoff et al. 2015). Rhinocricidea has only the family Rhinocricidae Brölemann, 1913 which is the largest family in the order Spirobolida with more than 575 species and 30 genera (Marek et al. 2003; Pitz \& Sierwald 2010; Enghoff et al. 2015). These genera are grouped into three subfamilies, Rhinocricinae Brölemann, 1913, Oxypyginae Chamberlin, 1922 and Poecilocricinae Schubart, 1962. The genus Erythrocricus Schubart, 1962 represents one of the Brazilian genera of the subfamily Rhinocricinae. The genus was proposed by Schubart (1962) as a subgenus of Rhinocricus Karsch, 1881, based on the shape of the gonopods and a transverse red line in the dorsal part of the metazonites of the body rings. Two species were described, the type species Rhinocricus (Erythrocricus) sanguineostriatus 
Schubart, 1962 from the states of São Paulo and Goiás and Rhinocricus (Erythrocricus) miniatostriatus Schubart, 1962 from the state of Goiás. In the description of both species, Schubart (1962) described the great similarity between them, with the difference based only on details of the red coloration. Hoffmann (1980) raised Erythrocricus to the genus level but did not justify the proposed new status or whether he examined the species of the genus. In the present study, we revise the genus Erythrocricus. The type species Erythrocricus sanguineostriatus Schubart, 1962 is considered a senior synonym of Erythrocricus miniatostriatus (Schubart, 1962), and the species Rhinocricus electrofasciatus (Schubart, 1957) is transferred to the genus Erythrocricus. A redescription of these species, based on fresh specimens and the type material, is presented. In addition, a key to males of the genus and new illustrations of the species are presented.

\section{Material and methods}

The examined material is deposited in the institutions indicated below (curators in parentheses). The specimens are preserved in $70 \%$ ethanol. For the examination of taxonomic characters, measurements and illustrations of the gonopods, we used a stereo microscope with a measuring eyepiece coupled to a drawing tube. Photographs were taken with a Motic SMZ171 stereo microscope camera in conjunction with a Motic Moticam 5+ digital imaging system software. To edit images, we used CorelDRAW Graphics Suite X5. For the gonopod terminology and external characters, we followed Enghoff et al. (1993), Koch (2015) and Rodrigues et al. (2020).

\section{Repositories}

CZUFMT MYR = Coleção Zoológica da Universidade Federal do Mato Grosso, Cuiabá, Mato Grosso, Brazil (A. Chagas-Jr)

MZSP $\quad=$ Museu de Zoologia, Universidade de São Paulo, São Paulo, Brazil (R. Pinto da Rocha)

MCN = Museu de Ciências Naturais, Porto Alegre, Rio Grande do Sul, Brazil (R. Ott)

\section{Morphological abbreviations}

$\begin{array}{ll}\mathrm{Br} 2, \mathrm{Br} 3, \ldots \mathrm{Br} 9 & =\text { body ring } 2 \text {, body ring } 3, \ldots \text { body ring } 9 \\ \mathrm{Co} & =\text { collum } \\ \mathrm{Cx} & =\text { coxae } \\ \mathrm{Cxt} & =\text { external branch } \\ \mathrm{Eb} & =\text { epiproct } \\ \mathrm{Ep} & =\text { hypoproct } \\ \mathrm{Hp} & =\text { metazonites } \\ \mathrm{Mt} & =\text { paraproct } \\ \mathrm{Pr} & =\text { solenomere } \\ \mathrm{Sl} & =\text { sternite } \\ \mathrm{St} & =\text { telopodite } \\ \mathrm{Tl} & \end{array}$




\section{Results}

\section{Taxonomy}

Order Spirobolida Bollman, 1893

Suborder Rhinocricidea Brölemann, 1913

Family Rhinocricidae Brölemann, 1913

Subfamily Rhinocricinae Brölemann, 1913

Genus Erythrocricus Schubart, 1962

Erythrocricus Schubart, 1962: 69, as subgenus of Rhinocricus Karsch, 1881 (type species: Rhinocricus (Erythrocricus) sanguineostriatus Schubart, 1962).

Erythrocricus - Hoffman, 1980: 79 (new status).

Rhinocricus (Erythrocricus) sanguineostriatus - Marek et al. 2003: 71.

\section{Diagnosis}

Species of Erythrocricus differ from other rhinocricid genera by the combination of the following characters: both males and females have a transverse red line on body rings (Figs 1B, D-F, 3C-D), males present a sternite of the anterior gonopods triangular in anterior view and a rounded coxite (Figs $2 \mathrm{~A}$, $5 \mathrm{~A}$ ), each posterior gonopod has the external branch folded over the solenomere (Figs 2C, 5C).

\section{Species included}

Erythrocricus sanguineostriatus (Schubart, 1962)

Erythrocricus electrofasciatus (Schubart, 1957) comb. nov.

\section{Distribution}

Occurring in the Atlantic forest (state of São Paulo), Cerrado biome (state of Goiás), and in the Amazonian and Pantanal biomes (Mato Grosso) of Brazil.

\section{Key to species of Erythrocricus (based on males)}

1. Red coloration on collum, telson and all metazonites as a transverse red line dorsally (Fig. 1B, D-F), lobe of telopodite of anterior gonopod reduced in posterior view (Fig. 2B)

E. sanguineostriatus (Schubart, 1962)

- Red coloration as a transverse red line in dorsal portion only on anterior metazonites, lobe of telopodite of anterior gonopod well-developed in posterior view (Fig. 5B)

\section{E. electrofasciatus (Schubart, 1958) comb. nov.}

\section{Erythrocricus sanguineostriatus (Schubart, 1962)}

Figs 1-3

Rhinocricus (Erythrocricus) sanguineostriatus Schubart, 1962: 70, figs 1, 2, 4.

Rhinocrinus (Erythocricus) sanguineostriatus — Marek et al. 2003: 72.

Erythrocricus miniatostriatus Schubart, 1962: 71, figs 3, 5. Syn. nov.

\section{Justification of synonymy}

Schubart (1962) described two species, Erythrocricus sanguineostriatus and E. miniatostriatus, both similar in body pattern and gonopods structure. Despite the similarities, both species present variations in 

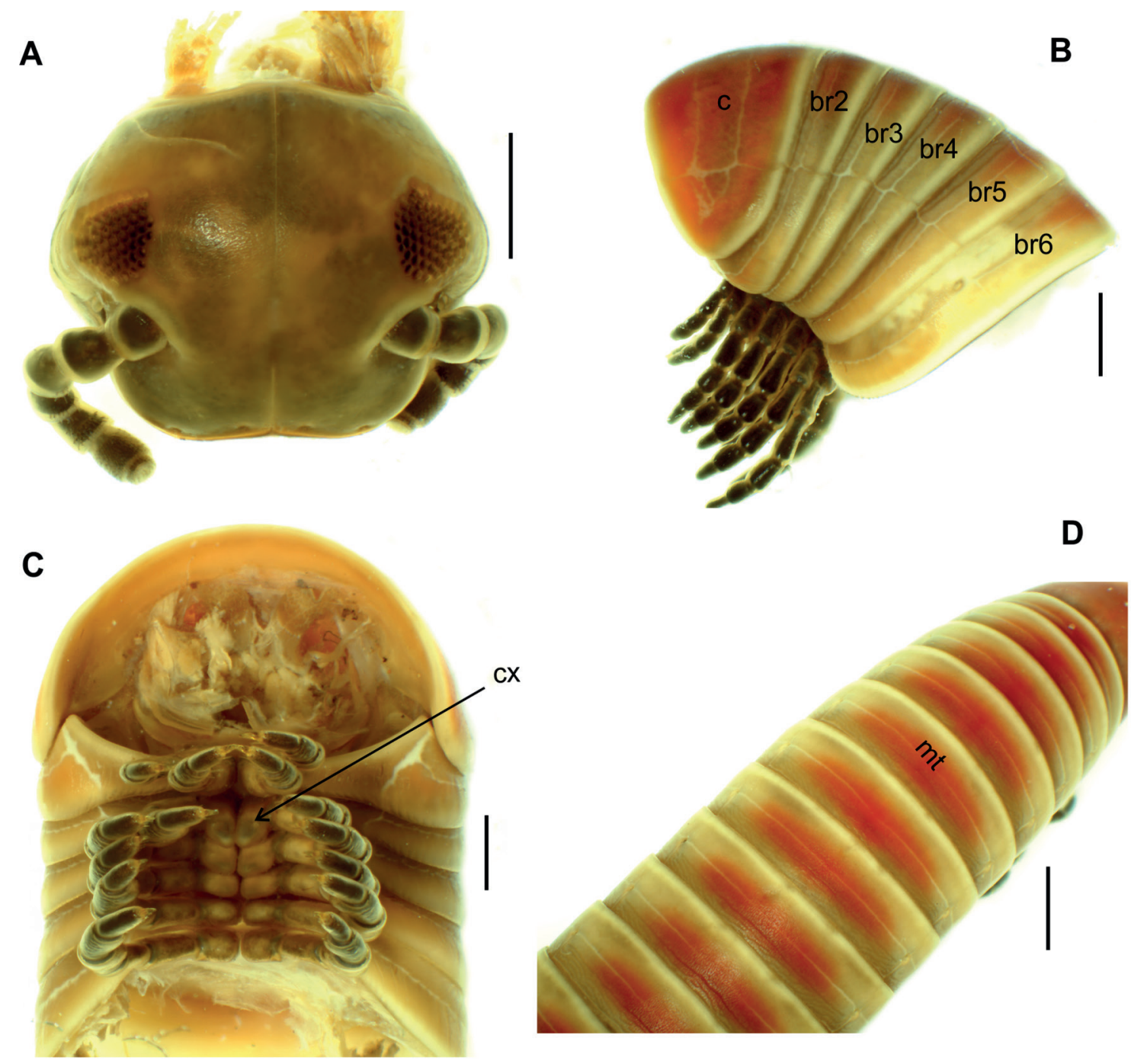

D
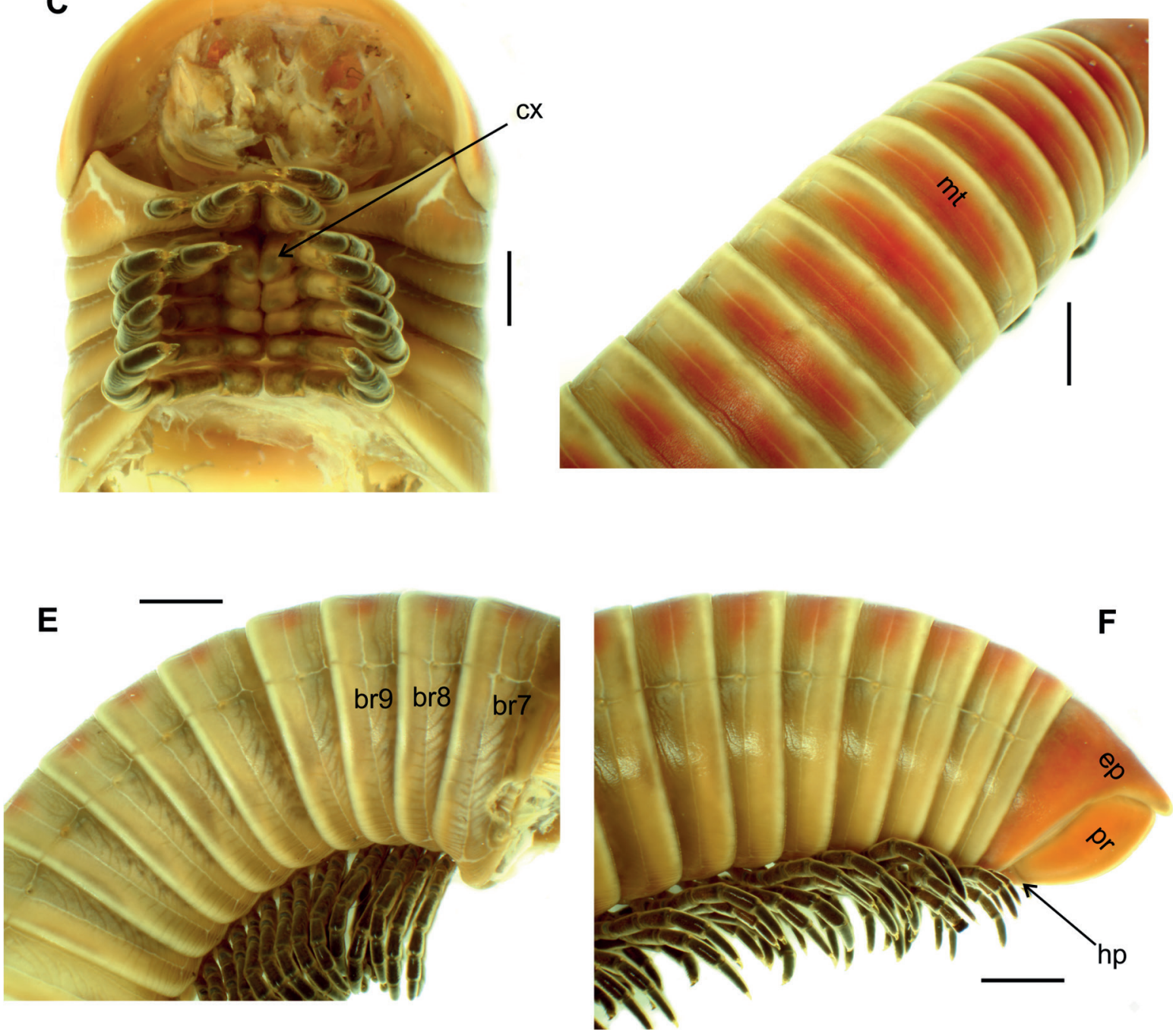

Fig. 1. Erythrocricus sanguineostriatus (Schubart, 1962), ठ̊ (MCN 406). A. Head. B. Anterior body rings, lateral view. C. Anterior body rings, ventral view. D. Posterior body rings, dorsal view. E. Midbody rings, lateral view. F. Posterior body rings and telson, lateral view. Scale bars $=1 \mathrm{~mm}$. 
the red coloration on body rings wich in E. sanguineostriatus is present dorsally and in E. miniatostriatus dorsally and ventrolaterally. Our examination of the type species revealed that there is no significant difference either in external morphology or the structure of the gonopods between the species. Still, during examination of fresh specimens, we observed that the differences in the red coloration, seems to reflect only intraspecific variation.

\section{Diagnosis}

Erythrocricus sanguineostriatus (Schubart, 1962) resembles E. electrofasciatus (Schubart, 1957) comb. nov. by the shape of the anterior gonopod (Figs 2A, 5A) with a triangular sternite having the medial portion distally rounded and the anterior gonopod wider than long but differs by the telopodite of the anterior gonopod with a reduced lobe in posterior view (Fig. 2B), and the red coloration presented as a transverse red line on all metazonites, collum and telson (Fig. 1B, D-F) and a rounded process of the coxae of leg pair 3 of the male (Fig. 1C).

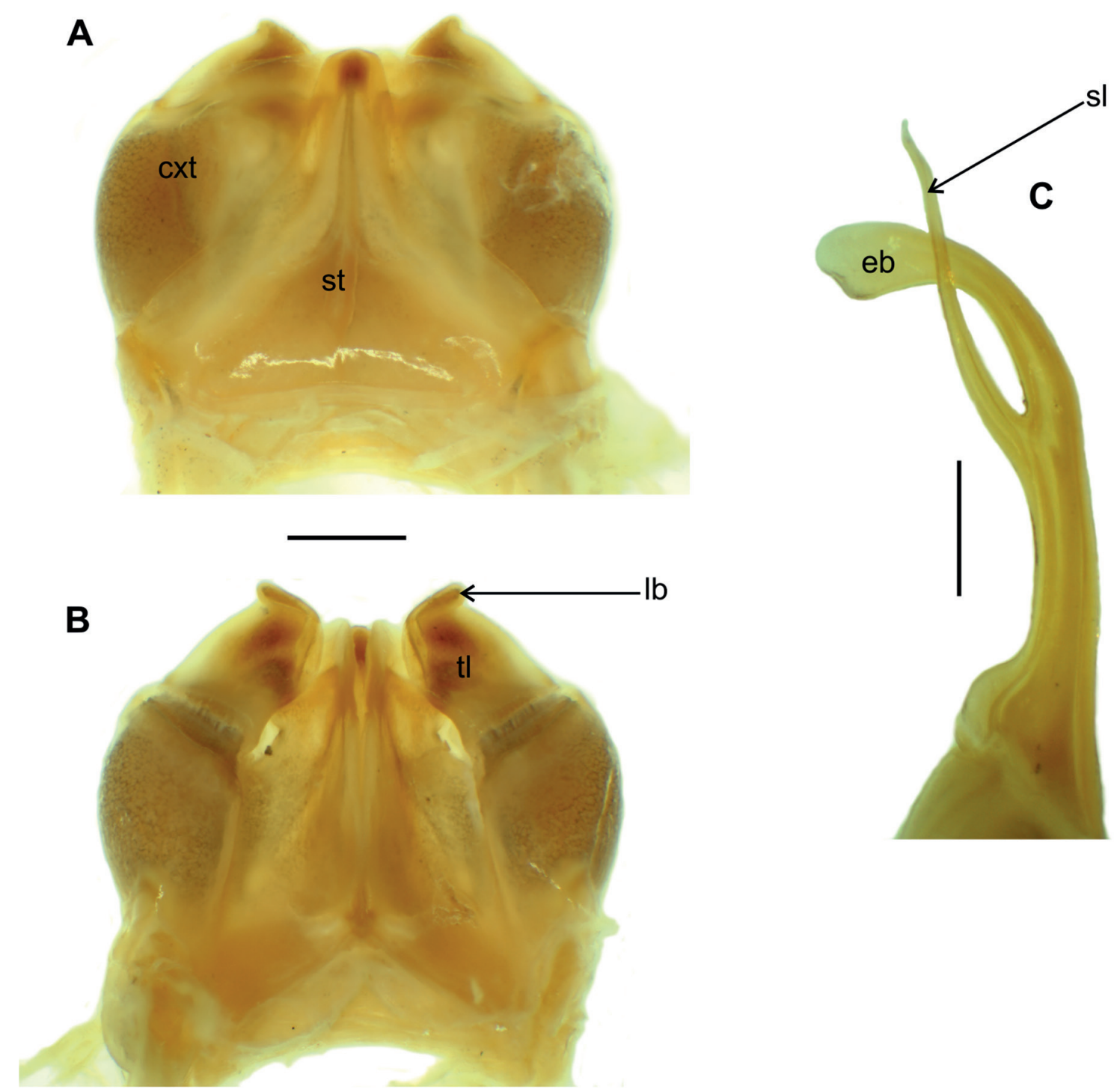

Fig. 2. Erythrocricus sanguineostriatus (Schubart, 1962), ô (MCN 406). A. Anterior gonopod, anterior view. B. Anterior gonopod, posterior view. C. Left posterior gonopod, anterior view. Scale bars $=1 \mathrm{~mm}$. 


\section{Material examined}

\section{Holotype}

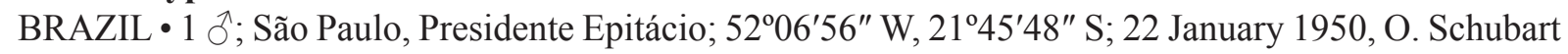
leg.; MZSP 2039.

\section{Paratypes}

BRAZIL・ 1 ô, 1 क; Goiás, Santa Helena de Goiás; 50³5'18" W, 17²9'23" S; Nov.1960, G.A. Oliveira leg.; MZSP 2114.

\section{Other material}

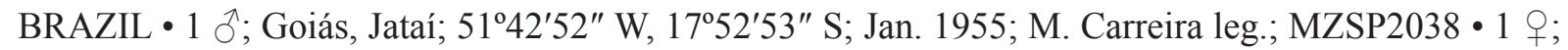

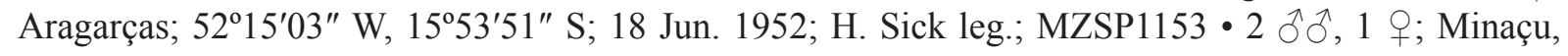

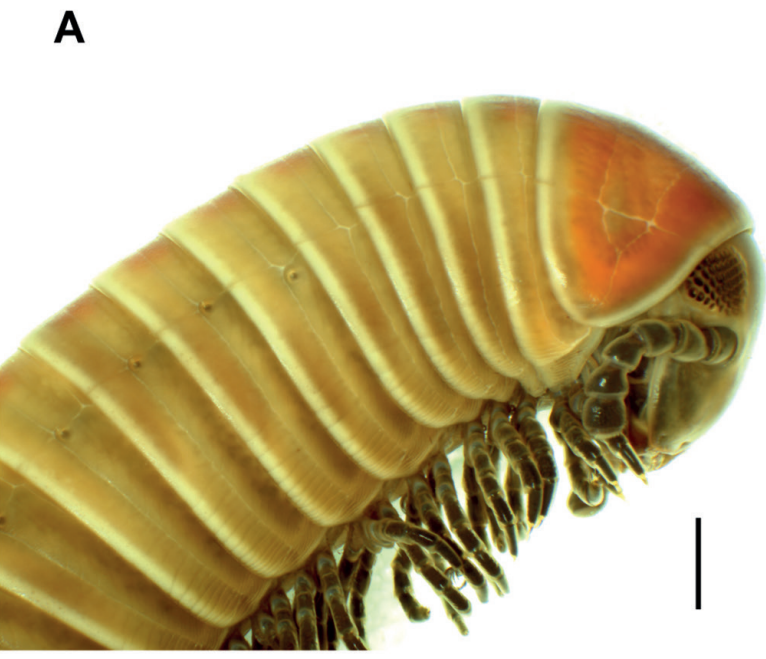

C

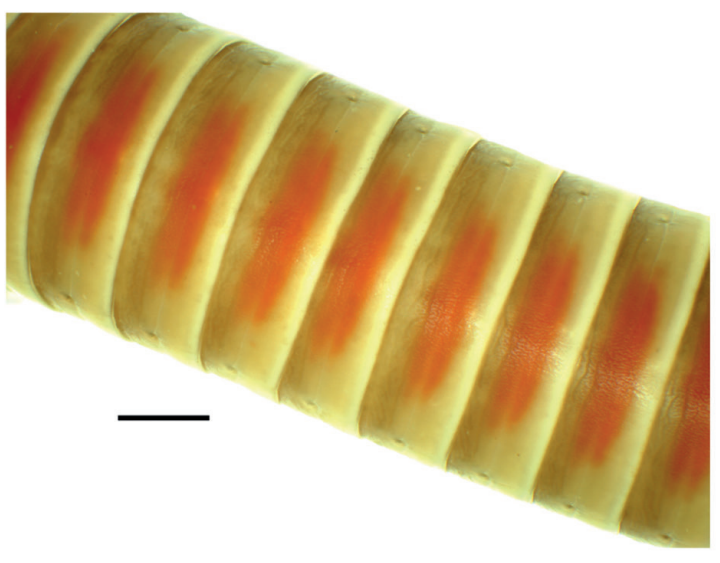

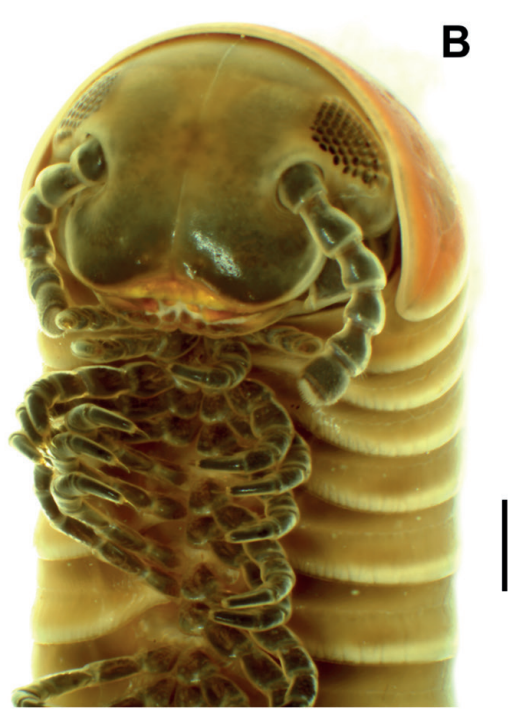

D

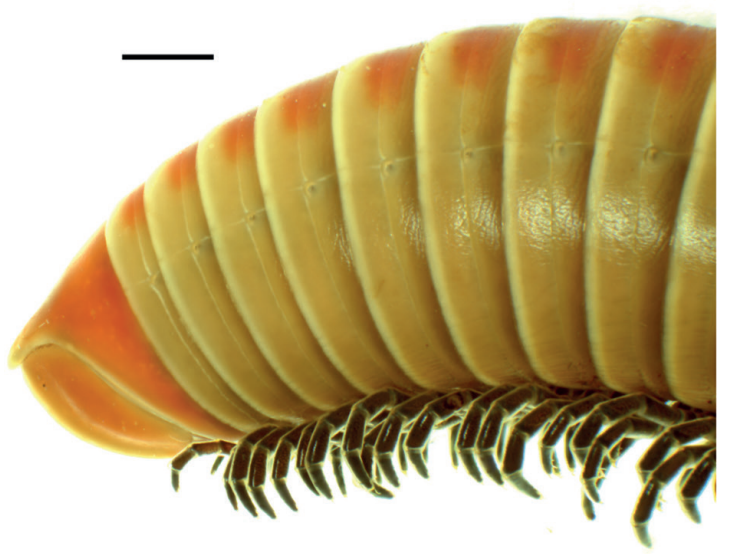

Fig. 3. Erythrocricus sanguineostriatus (Schubart, 1962), $q$ (MCN 406). A. Head and anterior body rings, lateral view. B. Head and anterior body rings, ventral view. C. Posterior body rings, dorsal view. D. Posterior body rings and telson, lateral view. Scale bars $=1 \mathrm{~mm}$. 
Usina Hidrelétrica Serra da Mesa; 48¹3'12" W, $13^{\circ} 31^{\prime} 59^{\prime \prime}$ S; $1-10$ Oct. 1990; A.B. Bonaldo and L.A. Moura leg.; MCN406.

\section{Redescription}

Male (MCN 406)

MEASUREMENTS. With 52p+1a+T. Total length $55.0 \mathrm{~mm}$, maximum width of midbody body rings $5.1 \mathrm{~mm}$.

Coloration (in 70\% alcohol) (Fig. 1). Antennae and legs dark brown. Collum red with yellowish margins. Prozonites grey; metazonites in dorsal portion with transverse red line on all body rings, posterior margins whitish. Telson red.

HEAD AND BODY RINGS (Fig. 1). Antennae with numerous apical sensory cones. Collum rounded laterally. Tegument smooth, without setae. Ozopores starting from $6^{\text {th }}$ ring. Scobinae starting from- $7^{\text {th }}$ ring, semicircular and small.

LeGs (Fig. 1C). Coxae of leg pairs 3-5 of male expanded into a process. Coxae of leg pair 3 rounded.

TELSON (Fig. F). Epiproct short, not extended over paraprocts. Hypoproct subtriangular.

Gonopods (Fig. 2). Anterior gonopod wider than long, sternite triangular, medial portion with rounded apex. Sternite as long as coxite and shorter than telopodite (Fig. 2A). Coxite rounded, in posterior view with margins projected medially. Telopodite thickened with reduced distal lobe (Fig. 2B). Posterior gonopod distally bifid. External branch laminated and folded over solenomere. Solenomere long and thin (Fig. 2C).

Female (MCN 406)

Coloration (Fig. 3) as in male, with 52p+T. Total length $56.0 \mathrm{~mm}$. Width $5.2 \mathrm{~mm}$.

\section{Distribution}

Known from Presidente Epitácio, state of São Paulo, and Santa Helena de Goiás, Minaçu, Aragarças, state of Goiás.

Erythrocricus electrofasciatus (Schubart, 1957) comb. nov.

Figs $4-5$

Rhinocricus electrofasciatus Schubart, 1957: 309, figs 1-6.

Rhinocricus electrofasciatus — Marek et al. 2003: 55

\section{Diagnosis}

Erythrocricus electrofasciatus resembles E. sanguineostriatus in the characteristics cited above for the diagnosis of E. sanguineostriatus but differs by the general coloration (Fig. 4) and by the transverse red line only on the posterior metazonites. Coxae of leg pair 3 with a pointed apex (Fig. 4B); the telopodite of the anterior gonopod is well developed in posterior view (Fig. 5B), the external branch of the posterior gonopod lamellated and narrow, distally long and slender (Fig. 5C). 

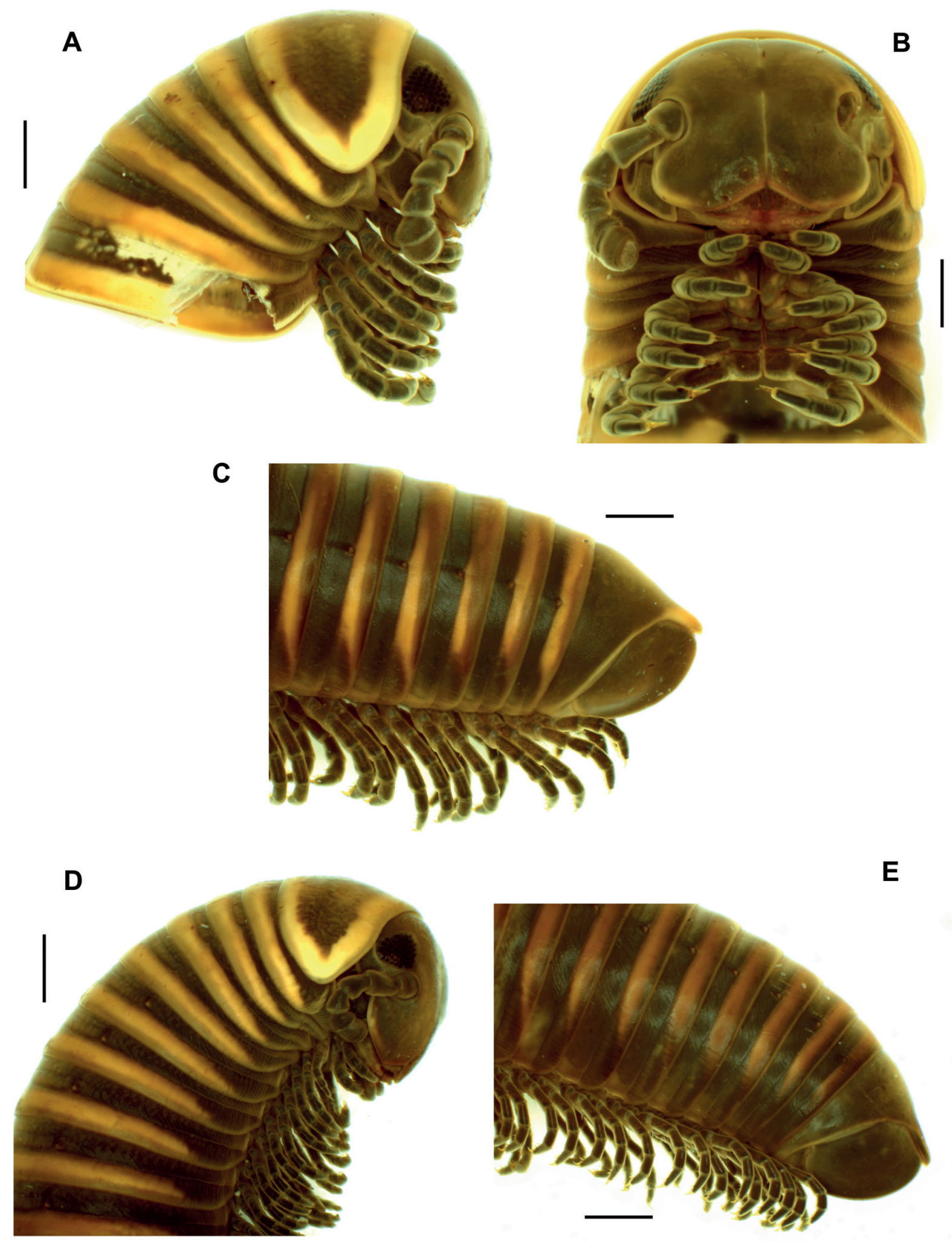

Fig. 4. Erythrocricus electrofasciatus (Schubart, 1957). A-C. $ぇ$ (MZUFMT-MYR0481). D-E. + (MZUFMT-MYR0481). A. Head and anterior body rings, lateral view. B. Head and anterior body rings, ventral view. C. Posterior body rings and telson, lateral view. D. Head and anterior body rings, lateral view. E. Posterior body rings and telson, lateral view. Scale bars $=1 \mathrm{~mm}$. 


\section{Material examined}

\section{Holotype}

BRAZIL • O’; Pará, Serra do Cachimbo; 5441'18.94" W, 90'39.85" S; 22 Sep. 1953; H. Sick leg.; MZSP 2, MZSP 3, MZSP 4, MZSP 081.

\section{Other material}

BRAZIL • 1 J, 1 q; Mato Grosso, Cotriguaçu; 58 25853’ W, 981926’ S; 2 Nov. 2014; M. Karam-

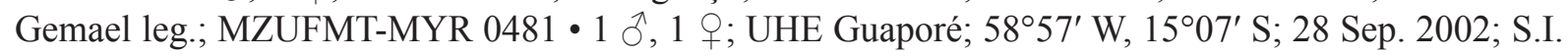
Golovatch et. al leg.; MZUFMT-MYR • 1 ô, 1 o+; 3 Oct. 2002; S.I. Golovatch et al. leg.; MZUFMTMYR.

\section{A}
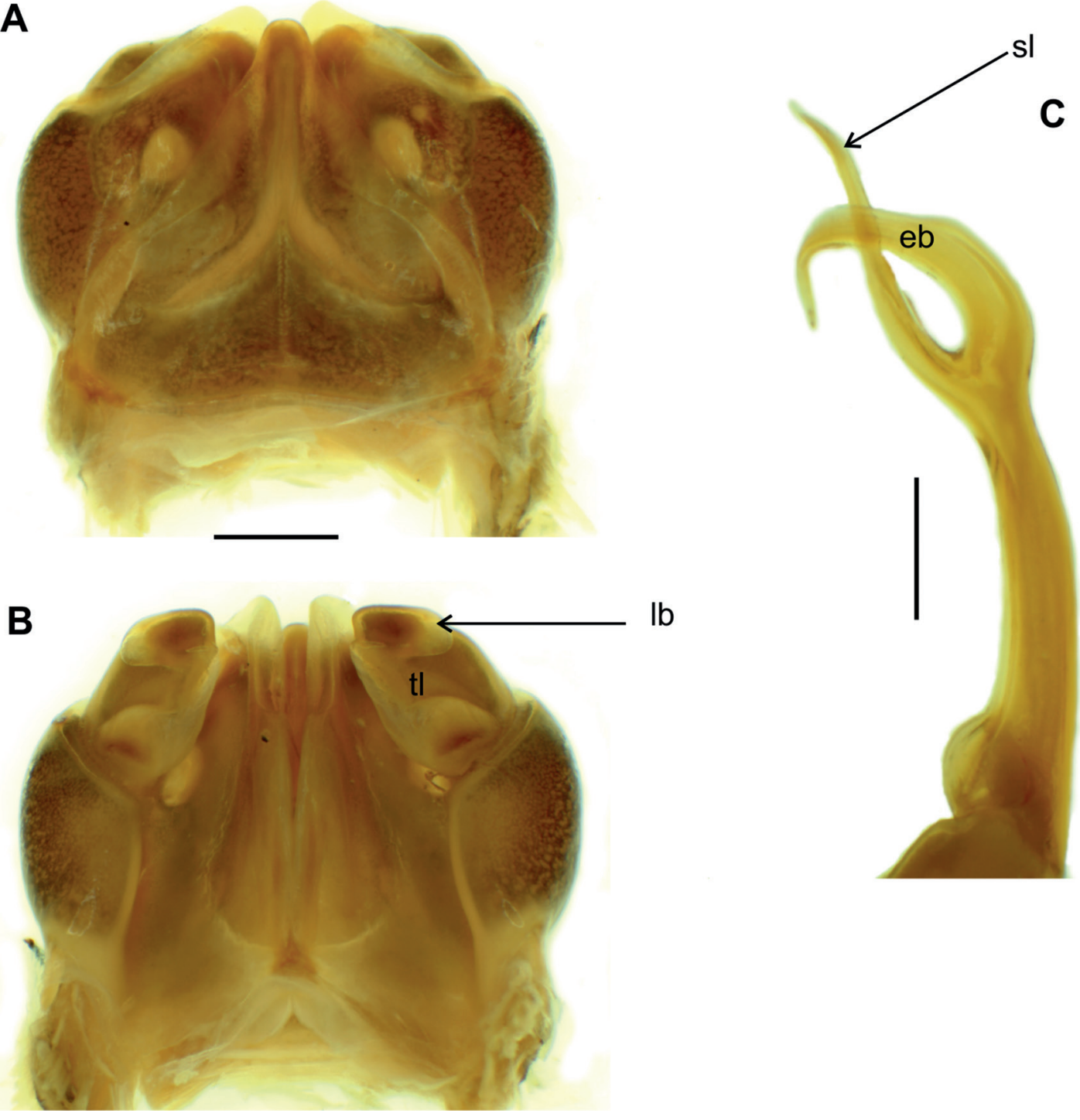

Fig. 5. Erythrocricus electrofasciatus (Schubart, 1957), $\widehat{\partial}$ (MZUFMT-MYR0481). A. Anterior gonopod, anterior view. B. Anterior gonopod, posterior view. C. Rigth posterior gonopod, posterior view. Scale bars $=1 \mathrm{~mm}$. 


\section{Redescription}

Male

MeAsurements. 1 ग, MZUFMT-MYR 0481: with 52p+T. Total length $60.0 \mathrm{~mm}$, maximum width of midbody rings $5.7 \mathrm{~mm}$.

Coloration (in 70\% alcohol) (Fig. 4). Antennae and legs dark brown. Collum in medial portion dark brown with yellowish margins (Fig. 4A). Prozonites dark brown; anterior metazonites yellowish with transverse red-ochre line in dorsal portion (not visible in Fig. 4A, but see Schubart 1957: 310), posterior metazonites amber (Fig. 4C). Telson dark brown (Fig. 4C).

HeAd AND Body RING (Fig. 4). Antennae with numerous apical sensory cones. Collum rounded laterally. Tegument smooth, without setae. Ozopores starting from $6^{\text {th }}$ ring. Scobinae starting from $7^{\text {th }}$ ring, concave.

LEgS (Fig. 4B). Coxae of leg pairs 3-5 of male expanded into a process. Coxae of leg pair 3 pointed.

TELSON (Fig. 4C). Epiproct short, not extended over paraprocts. Hypoproct subtriangular.

Gonopods (Fig. 5). Anterior gonopod wider than long, sternite triangular, medial portion with rounded apex. Sternite shorter than coxite, longer than telopodite (Fig. 5A). Coxite rounded, in posterior view apically with margins projected medially. Telopodite thickened, with well-developed distal lobe (Fig. 5B). Posterior gonopod distally bifid. External branch laminar and narrow, apically long and slender, folded over solenomere. Solenomere long and thin (Fig. 5C).

Female (MZUFMT-MYR 0481)

Coloration as in male (Fig. 4D-E), with 50p+T. Total length $61.0 \mathrm{~mm}$. Width $5.4 \mathrm{~mm}$.

\section{Distribution}

Known from Serra do Cachimbo, states of Pará, and state of Mato Grosso.

\section{Discussion}

Currently, two species are known to compose the millipede genus Erythrocricus, which is distributed in the Central-West and Southeast regions of Brazil. According to Schubart (1962), the genus is "purely Brazilian". As suggested by Schubart (1962), the genus Erythrocricus resembles Rhinocricus in the external morphology and gonopods. However, our review of the specimens revealed that details of the gonopods support the status of the genus as proposed by Hoffman (1980). Based on this examination, we proposed a new diagnosis for the genus. This work contributes to the knowledge of the full genus Erythrocricus because we provided more and new information from both males and females of the species and solved internal taxonomic problems.

\section{Acknowledgments}

We are grateful to Ricardo Pinto da Rocha and Mauro Cardoso Júnior (MZSP) and Amazonas ChagasJr (UFMT) for their hospitality during the visits and the loan of specimens. We thank Sergei Golovatch and the editor (Nesrine Akkari) for valuable comments and corrections on this paper. This study was partially supported by the Coordenação de Aperfeiçoamento de Pessoal de Nível Superior - Brazil (CAPES), Finance Code 001 (P.E.S. Rodrigues-88887.178957/2018-00). We thank the support by CNPq to Everton N.L. Rodrigues (process 422079/2018-9). 


\section{References}

Enghoff H., Dohle W. \& Blower J.G. 1993. Anamorphosis in millipedes (Diplopoda) - the present state of knowledge with some developmental and phylogenetic considerations. Zoological Journal of the Linnean Society 109: 103-234. https://doi.org/10.1111/j.1096-3642.1993.tb00305.x

Enghoff E., Golovatch S.I., Short M., Stoev P. \& Wesener T. 2015. Diplopoda - taxonomic overview. In: Minelli A. (ed.) Treatise on Zoology-Anatomy, Taxonomy, Biology. The Myriapoda. Vol. 2. Brill, Leiden / Boston. https://doi.org/10.1163/9789004188273_017

Hoffman R.L. 1980. Classification of the Diplopoda. Múseum d'histoire naturelle, Genève.

Koch M. 2015. Diplopoda - General morphology. In: Minelli A. (ed.) Treatise on Zoology - Anatomy, Taxonomy, Biology. The Myriapoda. Vol. 2. Brill, Leiden / Boston. https://doi.org/10.1163/9789004188273_003

Marek P.E., Bond J.E. \& Sierwald P. 2003. Rhinocricidae systematics II: a species catalog of the Rhinocricidae (Diplopoda: Spirobolida) with synonymies. Zootaxa 308: 1-108.

https://doi.org/10.11646/zootaxa.308.1.1

Rodrigues P.E.S., Campos L.A., Ott R. \& Rodrigues E.N.L. 2020. Phylogeny of three species groups of Rhinocricus Karsch, 1881 based on morphological characters (Diplopoda, Spirobolida, Rhinocricidae). Organisms Diversity \& Evolution 20:141-153. https://doi.org/10.1007/s13127-019-00421-3

Schubart O. 1957. Sôbre alguns Diplopoda da Serra do Cachimbo no Sul do Estado do Pará. Anais da Academia Brasileira de Ciências 29 (2): 309-318.

SchubartO. 1962. Novas espécies brasileiras da Família Rhinocricidae(Diplopoda, Opisthospermophora). Anais da Academia Brasileira de Ciências 34: 69-87.

Manuscript received: 25 November 2020

Manuscript accepted: 3 March 2021

Published on: 11 May 2021

Topic editor: Nesrine Akkari

Section editor: William Shear

Desk editor: Eva-Maria Levermann

Printed versions of all papers are also deposited in the libraries of the institutes that are members of the EJT consortium: Muséum national d'histoire naturelle, Paris, France; Meise Botanic Garden, Belgium; Royal Museum for Central Africa, Tervuren, Belgium; Royal Belgian Institute of Natural Sciences, Brussels, Belgium; Natural History Museum of Denmark, Copenhagen, Denmark; Naturalis Biodiversity Center, Leiden, the Netherlands; Museo Nacional de Ciencias Naturales-CSIC, Madrid, Spain; Real Jardín Botánico de Madrid CSIC, Spain; Zoological Research Museum Alexander Koenig, Bonn, Germany; National Museum, Prague, Czech Republic. 